to the bombardment of an electric discharge are, as Sir William Crookes has taught us, beautifully phosphorescent. I have here in this tube some thin crystalline plates of artificial ruby; they become beautifully phosphorescent when the current from the induction coil is passed through the tube, and by the kindness of Sir William Crookes I can show you some true rubies treated in a similar way. The behaviour of the artificial rubies in the vacuum tube is not quite as brilliant as that of the natural ones, but hitherto no special attention has been devoted to their preparation; they are simply thin plates broken from a large crystalline mass of slag such as that on the table. I may add that this variety of corundum produced by the burning of aluminium is very hard, and may be used, not only for the same purposes as ordinary corundum, but for lining the crucible in which the operations are conducted, so that the product of combustion takes its place in conducting the process. My warmest thanks are due to Dr. Goldschmidt for lending me the beautiful specimens on the table, and to Mr. W. H. Merrett for his aid in conducting the experiments.

I have set before you the considerations respecting the use of metals as fuel simply as they appear to flow. I trust that the adoption of the title of this lecture has been justified by the evidence given as to the possibility of using metals as fuel in the strictest sense of the word. It is well to be accurate on this point because we are told that the first known appearance of the word "fuel" in the English language occurs in a poem (Coeur de Lion, I 5 th century), and seems to have been a misinterpretation of the old French word fouaille, and was adopted in the belief that sustenance for the body and food for the flames are synonymous. Widening our view of metals by grouping them with fuels will be acceptable because fire and flame powerfully appeal to our thoughts. We "kindle" enthusiasm, and add "fuel" to the fire of ambition, in fact we constantly use fire, flame and fuel as similes, and any prospect of extending their use to us as such by enlisting metals in the service will be welcome. An early Italian metallurgist, Vanoccio Biringuccio, might not have thought so, for I find that, writing in the sixteenth century, he quaintly devotes the last chapter of a work on metallurgy to "Fires which burn and leave no ashes." In this chapter he appeals to envy, hatred, malice and other products of a kindled imagination, and traces their analogies to fuel and flame, but he speedily takes leave of his readers in alarm at the prospect such a treatment of the subject presents.

The burning of aluminium as fuel gives us sapphires and rubies in the place of ashes, and metallic fuel is burnt, not by the air above, but by the oxygen derived from the earth beneath, as it occurs in the red and yellow oxides to which our rocks and cliffs owe their colour and their beauty.

\section{AGRICULTURAL EXPERIMENTS.}

A NUMBER of reports on agricultural experiments conducted by provincial colleges have reached us, of which the most comprehensive is that issued by the Agricultural Department of the Durham College of Science. Most of the field-work that this report deals with was planned and started by Prof. Middleton's predecessor, and the results are becoming more valuable each year. It is a report that should be in the hands of every one that is interested in agricultural progress, though no one need expect to find it light reading.

In the north of England, as in many other parts of the country, the turnip crop suffers severely from finger and toe, and the work of the Durham College of Science is throwing much fresh light on this subject. Hitherto the disease has chiefly been combated by the application of large dressings of slaked lime applied a year or less before it was intended to grow a cruciferous crop. In this way the fungus and its spores are destroyed more or less effectively, but at a larger cost than agriculture can now well bear. It appeared, however, that if lime can get rid of the disease when the substance is applied only a short time before the crop that the fungus affects is to be grown, the clearance of the soil will be much more effectual-or will be accomplished at less outlay-if the trouble is attacked at its fountainhead, namely, directly after an infected crop has been grown. With this object in view, a field that had grown a much-diseased crop

1 "De la Pirotechnia," 1540, p. 167. (Venice). "Del fuocho che consuma et non facenere.

NO. I658, VOL. 64] in 1896 was divided into five plots in the autumn of that year, one of the plots being soon afterwards treated with $2 \frac{1}{2}$ tons per acre of ordinary burned lime, while another plot did not receive its dressing till the autumn of 1899 . Following the four-course shift the field was again under turnips in 1900 , with the follow. ing result per acre:-

\begin{tabular}{|c|c|c|c|c|}
\hline & \multicolumn{2}{|c|}{ Weight of roots } & \multicolumn{2}{|c|}{ Percentage } \\
\hline & Sound & Diseased & $\begin{array}{c}\text { Diseased } \\
\text { and } \\
\text { destroyed }\end{array}$ & Sound \\
\hline & Tons cwt. & Tons cwt. & & \\
\hline No lime $\ldots \quad \ldots \quad \ldots$ & I3 18 & $\begin{array}{ll}2 & 17\end{array}$ & $41 \cdot 6$ & $58 \cdot 4$ \\
\hline Lime applied, Feb. I897... & 20 II & O I3 & IO'I & 89.9 \\
\hline$" \quad, \quad$ Nov. I899... & $\begin{array}{ll}15 & 12\end{array}$ & I $\quad$ I3 & $29 \cdot 2$ & $70 \cdot 8$ \\
\hline
\end{tabular}

The above figures hardly put the case so strongly as they might, for whereas when the roots were diseased to the extent of $4 \mathrm{I}^{\circ} \mathrm{6}$ per cent. and $29^{\circ} 2$ per cent., such roots were practically valueless, the infected roots were far from the putrescent stage when the percentage of disease was IO' I.

The now well-known Cockle Park experiments on "manuring for mutton" are described at length in the above report, and are popularly presented in a circular issued by the Northumberland County Council. In this circular the results for each plot are shown by a diagrammatic sheep, the sections of whose body represent $(a)$ the growth due to the soil in its unimproved condition; $(b)$ the growth induced by manurial treatment; and (c) the portion of such growth as is needed to cover the manurial outlay. So far a large dressing of basic slag applied four years ago, and not repeated, has proved most effective; whereas the lowest place is taken by a moderate dressing of lime. A corresponding circular deals with the experiments on turnip manuring.

\section{UNIVERSITY AND EDUCATIONAL INTELLIGENCE.}

A well-arranged calendar of the Merchant Venturers' Technical College, Bristol, showing the courses of work to be taken in the forthcoming session and the facilities for study, has been received. At the end of each syllabus a useful list of books of reference is given, in addition to the usual list of text-books. We assume that the reference books recommended are to be found in the school library, or on the laboratory bookshelf.

A vacarion course of lectures and observations connected with nature study, for teachers in rural schools, was opened at the Harper-Adams Agricultural College, Newport, Salop, on August I with an address by the principal, Mr. P. Hedworth Foulkes. The primary object of nature teaching is, he pointed out, to encourage and promote in children the power of observation, so that when the school days are over the pupil is in full and complete sympathy with natural knowledge, and takes an intelligent interest in it. The course has been arranged to help teachers who are desirous of cultivating this spirit of observation and inquiry in their pupils.

Prof. W. J. Ashley, now one of the professors of economics in the Harvard University, Cambridge, Massachusetts, has been appointed to the first or organising chair of the future faculty of commerce in the University of Birmingham. Prof. Ashley was a Brackenbury scholar at Balliol College, Oxford, and obtained a first in history in $188 \mathrm{r}$, followed by a fellowship of Lincoln College. For three years he was college tutor in Oxford, lecturing in large classes in economics and history. Towards the end of the eighties he was called to a chair of economics at Toronto, and after a short time the staff of Harvard University went out of the ordinary course to enable provision to be made among them for him, and there he has occupied the chair of economic history since 1892 , the chair of economics itself being held by Prof. Taussig. It is understood to be the wish of the council and senate of the University of Birmingham that the professor should devote his first year to investigation and consolidation of ideas, in consultation with men of business in this and other countries, 
and that the faculty of commerce should not be constituted, or regular teaching begin, until the following session.

THE Royal Commissioners for the Exhibition of $185^{1}$ have made the following appointments to science research scholarships for the year 190I, on the reconmmendation of the authorities of the several universities and colleges. The scholarships are of the value of $150 l$. a year, and are ordinarily tenable for two years (subject to a satisfactory report at the end of the first year) in any university at home or abroad, or in some other institution approved of by the Commissioners. The scholars are to devote themselves exclusively to study and research in some branch of science, the extension of which is important to the industries of the country:-J. A. Craw, University of Glasgow F. Horton, University of Birmingham; A. Slator, University of Birmingham ; R. B. Denison, Yorkshire College, Leeds; G. Owen, University College, Liverpool ; G. Senter, University College, London; F. W. Rixon, Owens College, Manchester; T. Baker, Durham College of Science, Newcastle-on-Tyne; S. C. Laws, University College, Nottingham; Alice E. Smith, University College of North Wales, Bangor; J. Hawthorne, Queen's College, Belfast ; R. K. McClung, McGill University, Montreal ; C. W. Dickson, Queen's University, Kingston, Ontario; G. Harker, University of Sydney; Dr. J. M. Maclaren, University of New Zealand. The following scholarships granted in 1900 have been continued for a second year on receipt of a satisfactory report of work done during the first year :-C. E. Fawsitt, University of Edinburgh; V. J. Blyth, University of Glasgow ; J. Moir, University of Aberdeen, Dr. W. M. Varley, Yorkshire College, Leeds; J. C. W. Humfrey, University College, Liverpool ; S. Smiles, University College, London; Alice L. Embleton, University College of South Wales and Monmouthshire, Cardiff; J. A Cunningham, Royal College of Science, Dublin; W. S. Mills, Queen's College, Galway ; J. Patterson, University of Toronto; W. C. Baker, Queen's University, Kingston, Ontario; J. Barnes, Dalhousie University, Halifax, Nova Scotia ; J. J. E. Durack, University of Sydney. The following scholarships granted in I 898 and I 899 have been exceptionally renewed for a third year :-L. N. G. Filon, University College, London; J. W. Mellor, University of New Zealand; F. W. Skirrow, Yorkshire College, Leeds; C. G. Barkla, University College, Liverpool ; W. Campbell, Durham College of Science, Newcastle-uponTyne; L. Lownds, University College, Nottingham; Dr. J. T Jenkins, University College of Wales, Aberystwyth; R. D. Abell, University College of North Wales, Bangor; B. D. Steele, University of Melbourne.

\section{SCIENTIFIC SERIAL.}

American Journal of Science, July.-Geology of the Shonkin Sag and Palisade Butte Laccoliths in the Highwood Mountains of Montana, by W. H. Weed and L. V. Pirsson.--On the manganese ore deposits of the Queluz (Lafayette) district, Minas Geraes, Brazil, by O. A. Derby.-On the bituminous deposits situated at the south and east of Cardenas, Cuba, by H. E. Peckham. On the north of Cuba there is a tract of country more than 4500 square miles in area, the springs and wells of which give indications of the existence of liquid bitumens of varying density. The oil which has been obtained resembles the oils of Russia, but it is doubtful if, in view of the enormous production which recent developments in Texas and Indiana promise, there is a present any encouragement for even experimental drilling in Cuba.-Mineralogical notes, No. 2, by A. F. Rogers. A description of new types of calcite and galena, together with a note of new localities for some rare minerals. - A new solution for the copper voltameter, by W. K. Shepard. A saturated solution of copper sulphate is boiled for a short time to expel the air and then kept for about an hour at $100^{\circ} \mathrm{C}$. in contact with metallic copper in order to neutralise the solution. About 05 per cent. of ammonium chloride was then added. Using this solution it was found that the weight of copper was practically independent of the temperature between $20^{\circ}$ and $40^{\circ} \mathrm{C}$; the solution may be used a large number of times, and the results are independent of the current density between the limits of 02 and ${ }^{\circ} 7$ ampere per square centimetre. - The thermomagnetic and galvanomagnetic effects in tellurium, by M. G. Lloyd.-Additions to the avifauna of the Bermudas, with diagnoses of two new subspecies, by A. H. Verrill.-The induced alternating current discharge studied with reference to its spectrum and especially its ultra-violet spectrum, by A. W. Wright and E. S. Downs,

No. I658, VOL. 64$]$

\section{SOCIETIES AND ACADEMIES.}

\author{
LONDON.
}

Royal Society, May 23.- "Preliminary Statement on the Prothalli of Ophioglossum pendulum (L.), Helminthostachys seylanica (Hook), and Psilotum, sp." By William H. Lang, M.B., D.Sc., Communicated by Prof. F. O. Bower, F.R.S.

During a recent visit to Ceylon and the Malay Peninsula, the author found prothalli of Ophivglossum pendulum and Helminthostachys zeylanica. as well as a single specimen, which there is reason to regard as the prothallus of Psilotum. This paper gives a brief account of the mode of occurrence and external form of these three prothalli.

Ophioglossum pendulum. The prothalli were found in the humus collected by an epiphytic fern. They were wholly saprophytic, devoid of chlorophyll and of a yellowish-white colour. An endophytic mycorhiza is present in them. The prothallus is radially symmetrical, the older ones consisting of a number of short cylindrical branches radiating in all directions into the humus. The surface of these branches is covered with short unicellular hairs (paraphyses); rhizoids are absent. The antheridia and archegonia, which occur on the same prothallus, resemble those of $O$. pedunculosum.

Helminthostachys zeylanica. The wholly saprophytic prothalli of this plant occur about two inches below the surface of the ground. They are radially symmetrical ; the lower vegetative half, in which is an endophytic fungus, is more or less lobed and bears rhizoids. The sexual organs are borne on the upper half; the antheridia are large and sunk beneath the surface ; the archegonia project slightly from it. Sometimes the prothalli are moncecious, but more often a prothallus bears antheridia or archegonia only. The ternate lamina of the first leaf of the young plant is green and appears above ground.

Psilotum. A single prothallus, presumably belonging to this plant, $\mathrm{x}$ as found embedded among the roots covering the stem of a tree-fern. It was one-quarter of an inch long and presented a general resemblance to some prothalli of Lycopodium, having a well-marked primary tubercle. The sexual organs were borne on the overhanging margin of the upper region of the prothallus, between which and the lower vegetative region the meristem will probably be found to be situated.

June 20.- "The Mechanism of the Electric Arc." By (Mrs.) Hertha Ayrton. Communicated by Prof. Perry, F.R.S.

The object of the paper is to show that, by applying the ordinary laws of resistance, of heating and cooling and of burning to the arc, considered as a gap in a circuit furnishing its own conductor by the volatilisation of its own material, all it's principal phenomena can be accounted for, without the aid of a large back E.M.F., or of a "negative resistance," or of any other unusual attribute.

\section{The Apparent Large Back E.M.F.}

It is shown how volatilisation may begin, even without the self-induction to which the starting of an arc, when a circuit is broken, is usually attributed; and it is pointed out that, when the carbons are once separated, all the material in the gap cannot retain its high temperature. The air must cool some of it into carbon mist or fog, just as the steam issuing from a kettle is cooled into water mist at a short distance from its mouth. The dissimilar action of the poles common to so many electric phenomena displays itself in the arc at this point. Instead of both poles volatilising the positive pole alone does. It is considered, therefore, that the arc consists of (I) a thin layer of carbon vapour issuing from the end of the positive carbon, (2) a bulb of carbon mist joining this to the negative carbon, and (3) a sheath of burning gases, formed by the burning of the mist, and the hot ends of the carbons, and surrounding both. The vapour appears to be indicated in images of the arc by a sort of gap between the arc and the positive carbon, the mist by a purple bulb and the gases by a green flame.

The flame is found to be practically insulating, so that nearly the whole of the current flows through the vapour and mist alone. It is suggested that the vapour has a high specific resistance compared with that of the mist, and that it is to the great resistance of this vapour-film that the high temperature of the crater is due, and not to any large back E.M.F. of which it is the seat. 